\title{
Surface Mass Balance of the Columbia Glacier, Alaska, 1978 and 2010 Balance Years
}

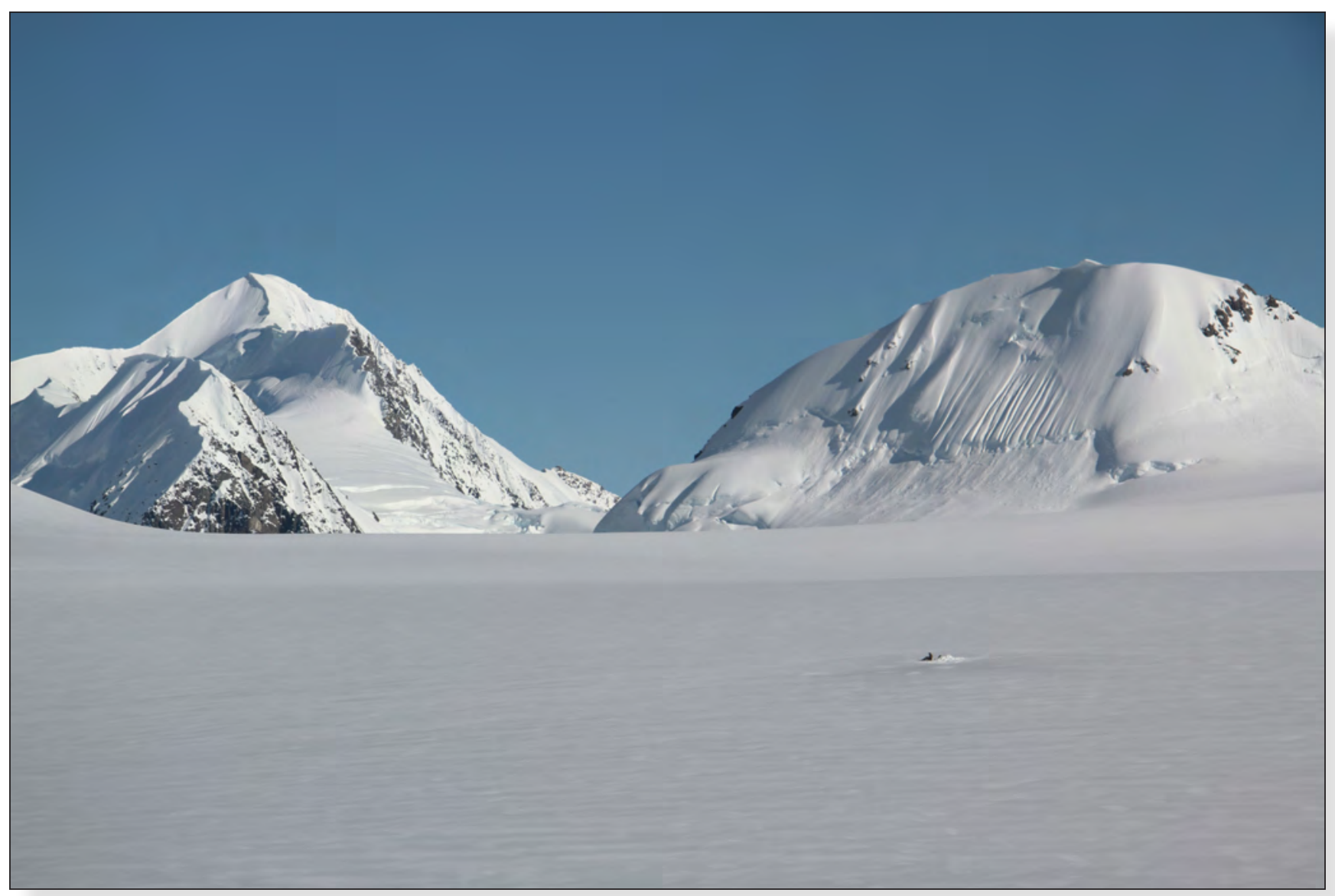

Data Series 676 
Cover: Researchers digging a snowpit in the accumulation zone of Columbia Glacier, Alaska. (Photograph taken by Shad O'Neel, U.S. Geological Survey, August 29, 2011.) 


\section{Surface Mass Balance of Columbia Glacier, Alaska, 1978 and 2010 Balance Years}

By Shad O'Neel

Data Series 676

U.S. Department of the Interior

U.S. Geological Survey 


\title{
U.S. Department of the Interior \\ KEN SALAZAR, Secretary \\ U.S. Geological Survey \\ Marcia K. McNutt, Director
}

\author{
U.S. Geological Survey, Reston, Virginia: 2012
}

For more information on the USGS - the Federal source for science about the Earth, its natural and living resources, natural hazards, and the environment, visit http://www.usgs.gov or call 1-888-ASK-USGS.

For an overview of USGS information products, including maps, imagery, and publications, visit http://www.usgs.gov/pubprod

To order this and other USGS information products, visit http://store.usgs.gov

Any use of trade, product, or firm names is for descriptive purposes only and does not imply endorsement by the U.S. Government.

Although this report is in the public domain, permission must be secured from the individual copyright owners to reproduce any copyrighted materials contained within this report.

Suggested citation:

O’Neel, Shad, 2012, Surface mass balance of Columbia Glacier, Alaska, 1978 and 2010 balance years: U.S. Geological Survey Data Series 676, 8 p. 


\section{Contents}

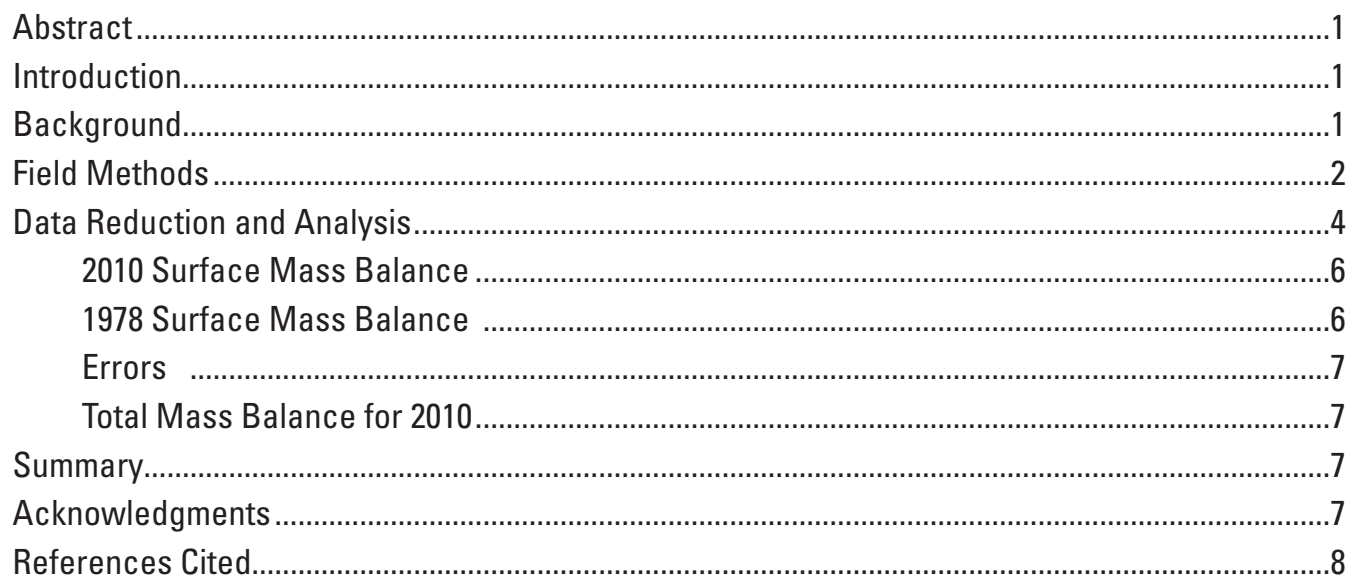

\section{Figures}

Figure 1. Map of Columbia Glacier, Alaska, showing several historical terminus positions

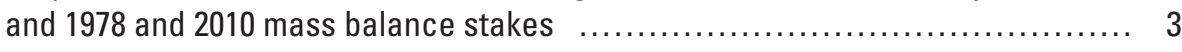

Figure 3. Graph showing area altitude distributions for Columbia Glacier, Alaska, from 1957 and 2007.

Figure 2. Graph showing fitted 2010 mass balance profile and all available surface mass balance data, Columbia Glacier, Alaska, balance years 1978 and $2010 \quad \ldots \ldots \ldots \ldots \quad 5$

\section{Tables}

Table 1. Locations, descriptions, and measurement types for 2010 mass balance campaign, Columbia Glacier, Alaska

Table 2. Site locations, specific balance, and assumed density for mass balance sites, Columbia Glacier, Alaska, 1978

Table 3. Fitting parameters for exponential balance profiles, Columbia Glacier, Alaska, balance years 1978 and 2010 


\section{Conversion Factors and Datums}

Conversion Factors

\begin{tabular}{lcl}
\hline \multicolumn{1}{c}{ Multiply } & By & \multicolumn{1}{c}{ To obtain } \\
\hline meter $(\mathrm{m})$ & Length & \\
kilometer $(\mathrm{km})$ & 3.281 & foot $(\mathrm{ft})$ \\
& 0.6214 & mile $(\mathrm{mi})$ \\
\hline square kilometer $\left(\mathrm{km}^{2}\right)$ & Area & \\
\hline & 0.3861 & square mile $\left(\mathrm{mi}^{2}\right)$ \\
\hline cubic meter $\left(\mathrm{m}^{3}\right)$ & Volume & \\
cubic kilometer $\left(\mathrm{km}^{3}\right)$ & 35.31 & cubic foot $\left(\mathrm{ft}^{3}\right)$ \\
& 0.2399 & cubic mile $\left(\mathrm{mi}^{3}\right)$ \\
\hline kilogram per cubic meter $\left(\mathrm{kg} / \mathrm{m}^{3}\right)$ & Density & \\
\hline
\end{tabular}

Datums

Vertical coordinate information is referenced to the World Geodetic System Ellipsoid of 1984 and revised and 2004 (WGS84).

Horizontal coordinate information is referenced to the World Geodetic System Ellipsoid of 1984 and revised and 2004 (WGS84).

Altitude, as used in this report, refers to distance above the vertical datum. 


\title{
Surface Mass Balance of Columbia Glacier, Alaska, 1978 and 2010 Balance Years
}

\author{
By Shad 0'Neel
}

\section{Abstract}

Although Columbia Glacier is one of the largest sources of glacier mass loss in Alaska, surface mass balance measurements are sparse, with only a single data set available from 1978. The dearth of surface mass-balance data prohibits partitioning of the total mass losses between dynamics and surface forcing; however, the accurate inclusion of calving glaciers into predictive models requires both dynamic and climatic forcing of total mass balance. During 2010, the U.S. Geological Survey collected surface balance data at several locations distributed over the surface of Columbia Glacier to estimate the glacier-wide annual balance for balance year 2010 using the 2007 area-altitude distribution. This report also summarizes data collected in 1978, calculates the 1978 annual surface balance, and uses these observations to constrain the 2010 values, particularly the shape of the balance profile. Both years exhibit balances indicative of near-equilibrium surface mass-balance conditions, and demonstrate the importance of dynamic processes during the rapid retreat.

\section{Introduction}

Columbia Glacier, located in the Chugach Mountains of Alaska, is one of the largest point sources of glacier mass loss in the Alaska Region (Arendt and others, 2006; Berthier and others, 2010). Since rapid calving retreat began during the early 1980s, the glacier mass has decreased by approximately $120-150 \mathrm{~km}^{3}$ water equivalent (w.e.) (Rasmussen and others, 2011; including mass loss occurring between 2007 and 2010 at a rate of $7 \mathrm{~km}^{3}$ w.e per year). Calving plays a dominant role in the mass loss process (Meier and Post, 1987; O’Neel and others, 2005), strongly affecting flow dynamics over large regions of the glacier through accelerated ice motion and drawdown of the glacier. The manifestation of this dynamic instability disproportionately affects the regional mass balance signal in a similar way as outlet glaciers in Greenland dominate mass loss for large regions of the ice sheet (van den Broeke and others, 2009). A robust understanding of the instability is needed to better understand sea level rise and the role of calving glaciers in the sea level budget.

The purpose of this report is to disseminate data from two surface mass balance (SMB) field campaigns (1978 and 2010) in a practical format. It describes methods applied during the 2010 field campaign, followed by a description of the 1978 dataset and the analysis applied to both data sets.

\section{Background}

A rich history of research provides a robust description of the evolving Columbia Glacier geometry and flow field prior to and during rapid retreat of the glacier (Krimmel, 2001; O'Neel and others, 2005). These efforts, initiated by U.S. Geological Survey (USGS) in the late 1970s, have been extended by academic research through the 1990s and 2000s. Recent results provide insight into the dynamic instability (Pfeffer, 2007), calving mechanics (O'Neel and others, 2007; Walter and others, 2010), and the role of dynamics on sea level rise (Pfeffer and others, 2008). Emphasis has centered on the dynamic processes (fast flow and calving) that exhibit primary control on mass loss, whereas measurements of surface mass balance are scarce. However, Rasmussen and others (2011) present a model-derived time series of surface mass balance, although model validation is problematic due to lack of ground-truth observations. Surface balance measurements are needed to constrain the relative magnitude of dynamic forcing to the magnitude of surface mass balance forcing, especially to better constrain regional- to global-scale mass balance estimates both in Alaska and in other regions where tidewater glaciers play a substantial role in regional mass balance (for example, Svalbard, Norway). The 2010 surface mass balance measurements presented in this report are the first of their kind at Columbia Glacier since 1978, when a more extensive effort was made by the USGS (Mayo and others, 1979). 


\section{Field Methods}

Field visits occurred during spring (May) and autumn (August and September) 2010. Ablation that occurred after the autumn visit was measured during spring 2011. The six markers installed in spring 2010 (ig. 1) measure melt throughout the summer months and allow an estimate of 2010 summer balance. The autumn visit included measurements of melt at the markers installed in spring, observations of the equilibrium line altitude (ELA), and measurements of snow accumulation in three snow pits and cores. Although determination of an annual balance typically requires a full year of observation, we were able to confidently measure snow accumulation by locating the 2009 summer surface, which was marked with volcanic ash from the eruption of Mt. Redoubt during spring 2009 (Thompson and West, 2010). Coordinates and description for each site are given in table 1.

The two styles of markers used in this study include stakes and wires, each drilled as much as $10 \mathrm{~m}$ into the glacier surface. Mass balance stakes consist of approximately 3-m sections of steel conduit, which are coupled together to form longer stakes. An insulating wooden plug is inserted into the bottom of the stake to prevent self-drilling of the steel stake. At lower stations, plastic-coated wire is anchored to the bottom of the hole using fishing weights, then tethered to a small tetrahedron left on the surface as a marker. In high ablation environments, wire markers are much less susceptible to hole enlargement and leans, which exacerbate measurement errors. The markers are not suitable for accumulation measurements.

Surface material was documented to be either snow or ice in spring, but snow depth measurements were unsuccessful. A winter balance profile collected at nearby Wolverine Glacier (Rod March, U.S. Geological Survey, written commun., 2010) just prior to the initial visit allowed us to roughly estimate snow depths across the ablation area using direct interpolation with the profile. Snow depth estimates were made only at altitudes that overlap with Wolverine Glacier (below $700 \mathrm{~m}$ ) and, although crude, they are the only available correction for missing snow depths.

End-of-season accumulation was determined through a combination of snow pit and core measurements, plus observations in freshly opened crevasses. The approximate position (altitude only, no cross-flow variability) of the ELA in three primary basins also was documented.

Table 1. Locations, descriptions, and measurement types for 2010 mass balance campaign, Columbia Glacier, Alaska.

[Coordinates are UTM zone 6 WGS84 and height above ellipsoid as measured only with handheld GPS. Abbreviations: m, meter; km, kilometer]

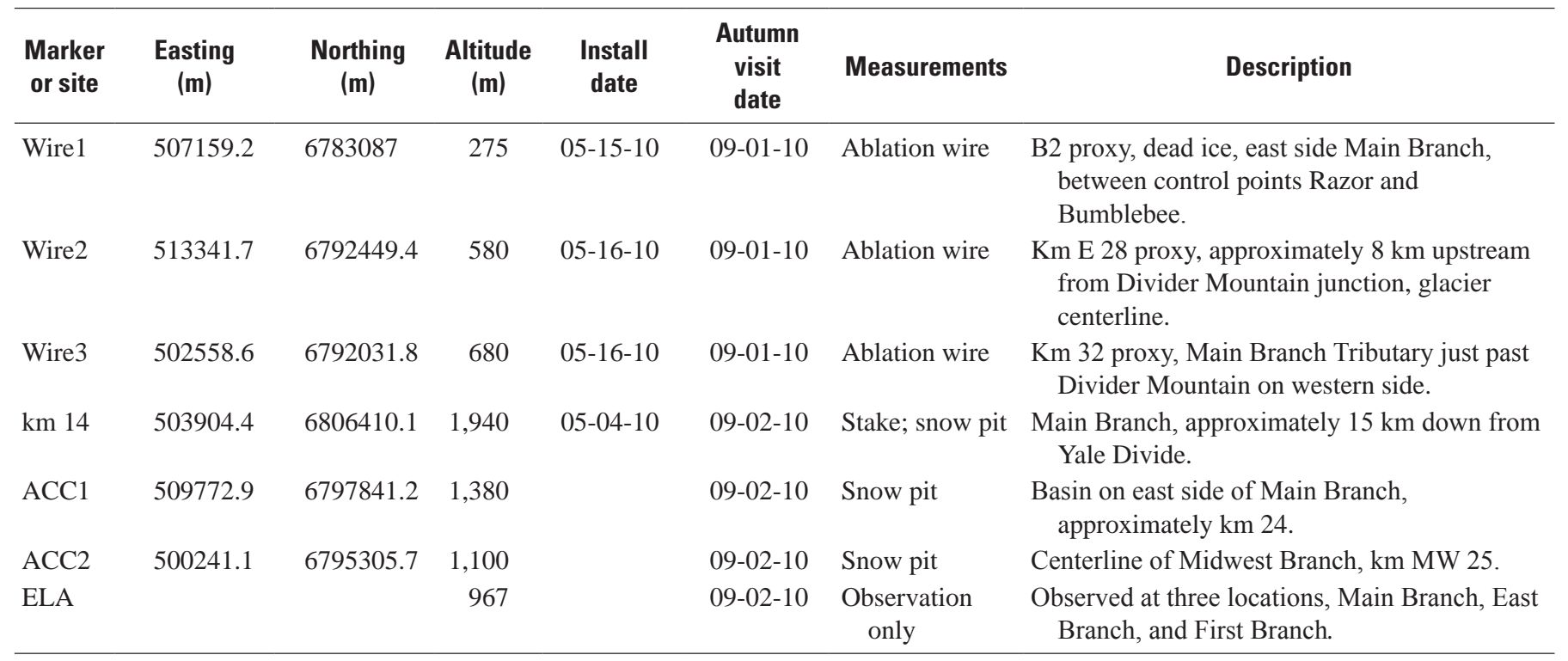




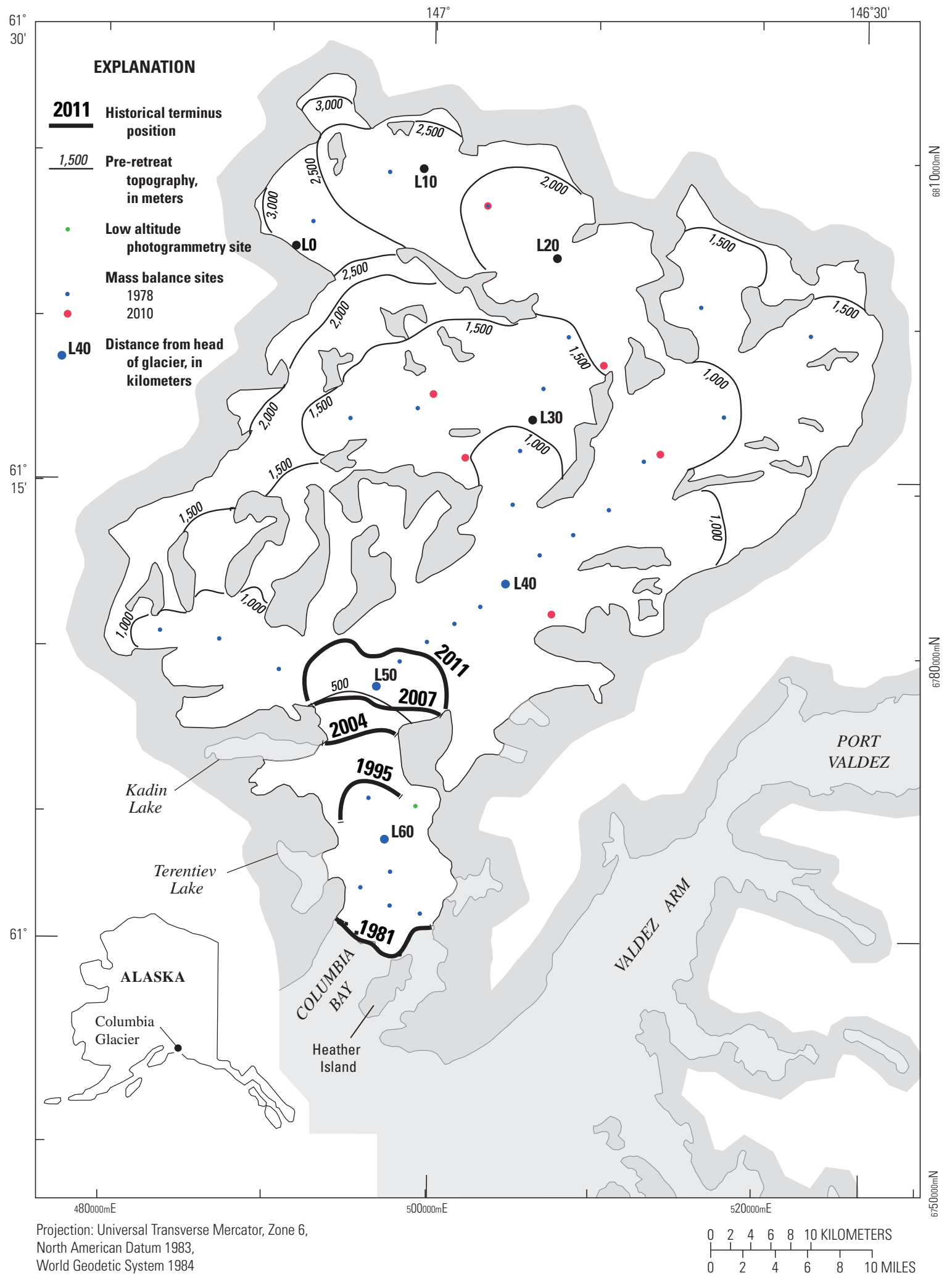

Figure 1. Columbia Glacier, Alaska, showing several historical terminus positions and 1978 and 2010 mass balance stakes. 


\section{Data Reduction and Analysis}

Data from each measurement site are presented as water-equivalent annual balances, where material density was measured or estimated. Annual refers to the balance year, with estimates calculated over the glacier mass balance year in a floating-date reference system (Cogley and others, 2011). Both summer and annual balances are resolved, and winter balances inferred as the residual. We determined water equivalencies at each point by (1) measuring the snow column height directly in a pit or pit/core, or (2) scaling the change in stake height (wire length) by the average density for the removed/ accumulated material. Glacier density was assumed to be $900 \mathrm{~kg} / \mathrm{m}^{3}$, and snow density was measured in pits and cores at 3-5 locations. The field visit during spring 2011 revealed additional melt of 1.0 and $0.2 \mathrm{~m}$ at the two lowest sites, which we incorporated into our analysis.

Data from balance year 1978 are published in Mayo and others (1979). We use 33 measurements, for which Mayo and others (1979) give coordinates, stake heights, and in some cases, density values. A subset of these data is presented in table 2, where previously published stake heights have been reduced to water-equivalent balances.

Photogrammetric surveys of stagnant ice near sea level between 1983 and 1996 (Krimmel, 2001) are used as a final data source. These surveys provided a low altitude $(150 \mathrm{~m})$ average annual balance of $-8.5 \mathrm{~m}$, which we adopted as an upper bound of melt rate because we were not able to access any ice that low.

Table 2. Site locations, specific balance, and assumed density for mass balance sites, Columbia Glacier, Alaska, 1978.

[Data from Mayo and others (1979). Coordinates are UTM zone 6 WGS84 and height above ellipsoid where the local reference frame given by Mayo and others (1979), has been transformed using a vertical shift of 15 meters, which is an average of four benchmarks resurveyed during 2009 using post-processed GPS surveys. Abbreviations: kg/m³, kilogram per cubic meter; km, kilometer; m, meter; w.e., water equivalent]

\begin{tabular}{|c|c|c|c|c|c|}
\hline Site name & $\begin{array}{l}\text { Easting } \\
\text { (m) }\end{array}$ & $\begin{array}{l}\text { Northing } \\
\text { (m) }\end{array}$ & $\begin{array}{l}\text { Altitude } \\
\text { (m) }\end{array}$ & $\begin{array}{l}\text { Point Balance } \\
\text { (m w.e.) }\end{array}$ & $\begin{array}{l}\text { Density } \\
\left(\mathrm{kg} / \mathrm{m}^{3}\right)\end{array}$ \\
\hline km 2 & 492909 & 6805649 & 2,653 & 5.1 & 520 \\
\hline km 8 & 497796 & 6809105 & 2,232 & 5.6 & 580 \\
\hline km 14 & 503371 & 6807249 & 1,930 & 3.0 & 620 \\
\hline $\mathrm{km} 24$ & 522431 & 6799146 & 1,464 & 1.2 & 600 \\
\hline km 28.2 & 506978 & 6795299 & 1,116 & .8 & 600 \\
\hline km 32 & 505161 & 6791649 & 951 & .0 & 600 \\
\hline km 35 & 504859 & 6788736 & 806 & -.8 & 800 \\
\hline $\mathrm{km} 40$ & 504850 & 6784167 & 675 & -2.3 & 850 \\
\hline $\mathrm{km} 42$ & 503402 & 6782808 & 644 & -2.9 & 850 \\
\hline km 44 & 501604 & 6781940 & 623 & -2.3 & 900 \\
\hline $\mathrm{km} 46$ & 500001 & 6780794 & 610 & -1.8 & 850 \\
\hline $\mathrm{km} 48$ & 498412 & 6779577 & 554 & -3.0 & 900 \\
\hline km 50 & 496775 & 6778370 & 526 & -2.1 & 900 \\
\hline $\mathrm{km} 58$ & 496725 & 6771023 & 544 & -5.6 & 900 \\
\hline km 60 & 497347 & 6768752 & 493 & -5.2 & 900 \\
\hline km 62 & 496943 & 6766507 & 199 & -4.7 & 900 \\
\hline km 62a & 499862 & 6767572 & 188 & -7.5 & 900 \\
\hline km 62b & 495389 & 6766188 & 181 & -6.8 & 900 \\
\hline km 64 & 499639 & 6764767 & 140 & -7.5 & 900 \\
\hline km E 24 & 516907 & 6794729 & 962 & -.2 & 600 \\
\hline km E 28 & 513601 & 6792546 & 898 & -1.1 & 750 \\
\hline km E 16 & 523276 & 6799378 & 1,359 & .7 & 600 \\
\hline km E 32 & 511069 & 6789345 & 789 & -1.2 & 750 \\
\hline $\mathrm{km} \mathrm{E} 36$ & 507901 & 6787106 & 723 & -1.9 & 750 \\
\hline km E 38 & 506338 & 6785602 & 697 & -1.6 & 750 \\
\hline km MW 20 & 495602 & 6794266 & 1,423 & 3.6 & 600 \\
\hline km MW 24 & 509812 & 6794814 & 1,247 & 2.1 & 600 \\
\hline km MW 28 & 503207 & 6795009 & 1,166 & 1.1 & 600 \\
\hline km NE 18 & 516863 & 6800524 & 1,143 & -.7 & 750 \\
\hline km W 40 & 484294 & 6781150 & 782 & .5 & 600 \\
\hline km W 44 & 488189 & 6780501 & 660 & -.2 & 800 \\
\hline km W 47 & 490866 & 6779183 & 591 & -1.2 & 850 \\
\hline RKA & 499562 & 6770908 & 195 & -8.5 & 900 \\
\hline
\end{tabular}


Each of these data points is plotted in the balance profile shown in figure 2. The profile demonstrates the nonlinear change in balance rate with altitude at Columbia Glacier. We chose an exponential fit $\left(z=971 e^{0.21 b}\right)$ to sample the 2010 balance profile at equal altitudes due to its robust nature $\left(\mathrm{R}^{2}=0.94\right)$, although it is unphysical near the ends. The divergence between the fit and physical behavior is greatest at high altitudes, where the glacier area is small (fig. 3).

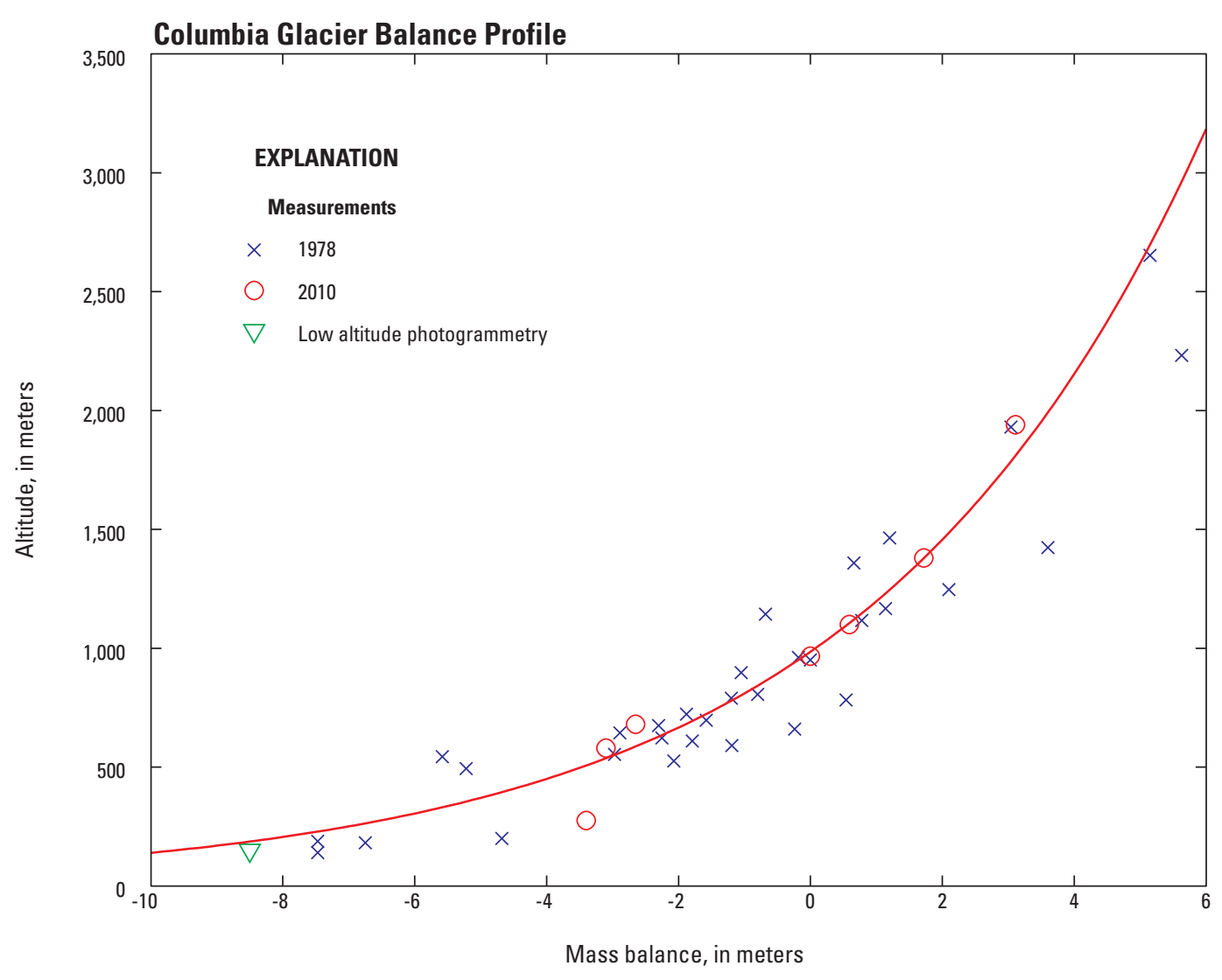

Figure 2. Fitted 2010 mass balance profile and all available surface mass balance data, Columbia Glacier, Alaska, balance years 1978 and 2010.

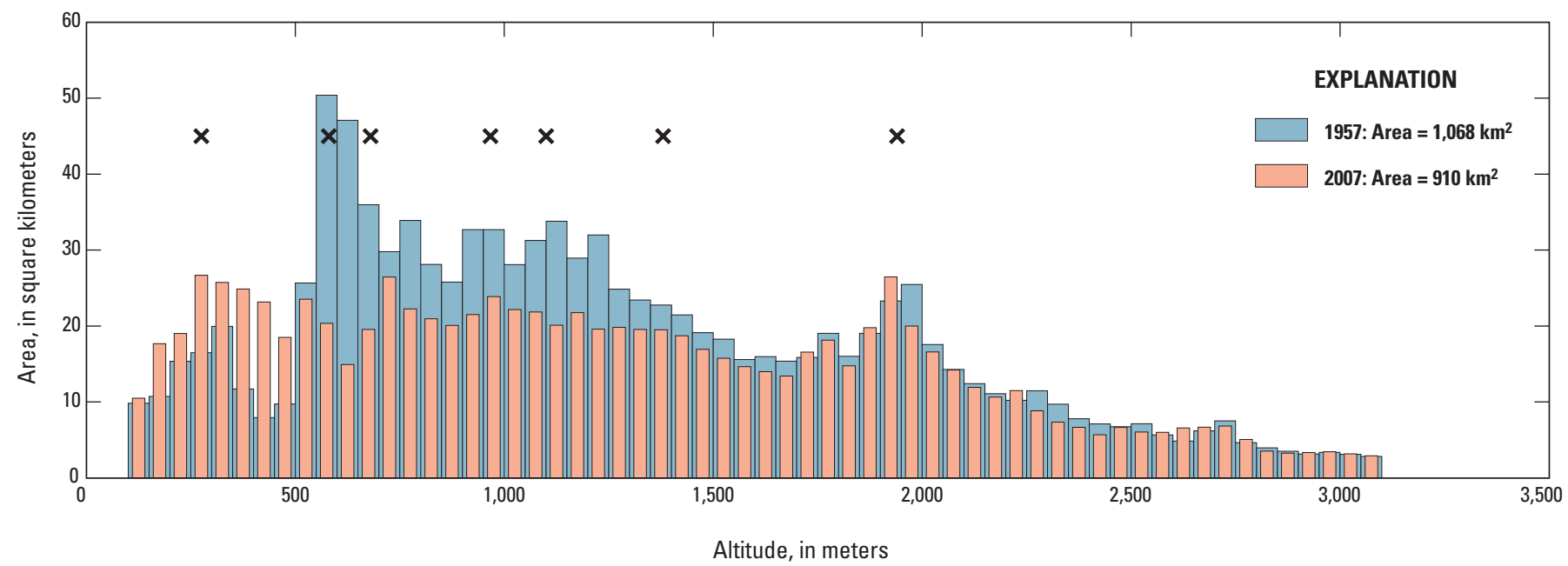

Figure 3. Area altitude distributions for Columbia Glacier, Alaska, from 1957 and 2007. Mass balance measurement site altitudes (2010) are given (x) to show their distribution relative to the glacier hypsometry. 
An area altitude distribution (AAD) is required to integrate point measurements over the glacier area. Two AADs are available spanning an altitude range from near sea level to $3,200 \mathrm{~m}$, and sampled at $50 \mathrm{~m}$ intervals. The first represents the pre-retreat glacier area in 1957, and the second represents the 2007 geometry (Spot DEM, http://www.alaskamapped. org/data/gallery/web-coverage-services/\#wcs-chugach-spot$\underline{\text { dem; }}$ glacier boundary manually digitized by UAF laser altimetry project). Figure 3 shows the two AADs, as well as the altitudes of the 2010 measurements, demonstrating that direct observations were made at altitudes that are strongly represented by the glacier hypsometry. We used the $2007 \mathrm{AAD}$ in our 2010 balance calculations as it most closely represents the present-day geometry of the glacier. The total area used is $910 \mathrm{~km}^{2}$. Estimates of the 1978 annual balance incorporate the 1957 AAD, which represents a similar geometry and has a total area of 1,068 $\mathrm{km}^{2}$.

\section{Surface Mass Balance}

The glacier-wide surface mass balance, $B_{a}$, is estimated by numerically integrating the balance profile over the AAD (for example, Cuffey and Paterson, 2010), neglecting lateral variations in balance across any contour. The average glacier-wide surface mass balance is obtained by scaling $B_{a}$ by the glacier area, and can be conceptualized as the thickness of a layer of water added or removed from the glacier surface. This integration yields a value of $B_{a}=+0.15 \mathrm{~m}$ w.e. $\left(S B_{a}=\right.$ $+1.39 \times 10^{8} \mathrm{~m}^{3}$ w. e.). A positive glacier-wide average balance is in qualitative agreement with local knowledge of a robust accumulation season and the estimated mass balance at nearby Wolverine Glacier.

The glacier-wide, summer, surface mass balance, $B_{s}$, is estimated at $-2.4 \mathrm{~m}$ w.e. $\left(S B_{s}=-2.17 \times 10^{9} \mathrm{~m}^{3}\right.$ w.e. $)$ This value represents the total volume loss during the summer months by climatic processes.

\section{Surface Mass Balance}

Mayo and others (1979) published point values of stake height change at approximately 60 locations on the glacier surface, but did not estimate point or glacier-wide mass balances. We have selected 33 of their stake measurements that have sufficient data to estimate the 1978 mass balances (table 2) and use these to estimate glacier-wide and glacier-wide average mass balance. When integrated over the $1957 \mathrm{AAD}$, point balances yield a glacier-wide balance, $B_{a}$, of +0.02 m w.e. $\left(S B_{a}=+2.45 \times 10^{7} \mathrm{~m}^{3}\right.$ w.e. $)$. A similar exponential fit is calculated $\left(\mathrm{R}^{2}=0.90\right.$; table 3$)$. The high point density for the 1978 data and the similar shape of the balance profiles provides confidence in the choice of the fitting parameters.

Table 3. Fitting parameters for exponential balance profiles, Columbia Glacier, Alaska, balance years 1978 and 2010.

[Confidence intervals are given in parentheses. Parameter a represents the fitted location of the ELA, and shows no statistically significant difference between the two years. $\mathrm{R}^{2}$, correlation coefficient]

\begin{tabular}{ccccc}
\hline $\begin{array}{c}\text { Balance } \\
\text { year }\end{array}$ & $\begin{array}{c}\text { Number } \\
\text { of points }\end{array}$ & $\mathbf{a}$ & $\mathbf{b}$ & $\mathbf{R}^{2}$ \\
\hline 1978 & 36 & $941(8741009)$ & $0.16(0.140 .19)$ & 0.89 \\
2010 & 7 & $971(8441098)$ & $0.21(0.130 .28)$ & 0.94 \\
\hline
\end{tabular}




\section{Errors}

Only surface mass balance is estimated in this report. All dynamic processes are neglected in our glacier-wide balance estimates, thus results represent only a small fraction of the total mass balance of Columbia Glacier. Quantification of uncertainty in direct mass balance estimates is difficult. Measurement site maintenance is costly and logistically challenging, so a minimal number of stakes were installed. Spatial variability in accumulation and ablation can be considerable both laterally across any glacier branch and between the numerous tributaries that flow into the terminus. Additionally, not all ablation results in mass loss; especially for a glacier that has an extensive accumulation area that retains cold snow, such as Columbia Glacier. In cold snow zones, a fraction of snowmelt is retained in the snowpack as internal accumulation. Our estimate ignored this process. To minimize these errors, measurements were made in three primary branches along the glacier centerline.

Quantitative uncertainties were estimated through sensitivity calculations around the observed ELA. Direct observations show the ELA varied in a $150 \mathrm{~m}$ zone in three branches of variable aspect. Uncertainty bounding the fitted parameter, $a$, which describes the ELA, matches direct observations well, and ranges over approximately $200 \mathrm{~m}$. The balance profile shown in figure 2 was shifted in $50 \mathrm{~m}$ intervals from -100 to $+100 \mathrm{~m}$ around the solution, and then the balance was recalculated to capture uncertainty in measurements. $A \pm 50 \mathrm{~m}$ shift in altitude for a given balance results in a $\pm 0.3 \mathrm{~m}$ w.e. change in the glacier-wide average-balance, with a positive bias. That is, if we erred on the side of an overly high ELA, the actual balance would be more positive than if we erred on the side of a low ELA due to the shape of the AAD. Expansion of the range to $\pm 100 \mathrm{~m}$ results in a linear expansion of uncertainty to \pm 0.6 , again with stronger changes when a higher ELA was assumed. These tests yield a best estimate of glacier-wide average balance of $+0.15 \pm 0.6 \mathrm{~m}$ w.e., suggesting 2010 was a near-equilibrium year. Uncertainty ranges for the 1978 data are about 25 percent smaller, suggesting a glacier-wide average balance of $+0.02 \pm 0.45 \mathrm{~m}$ w.e.

\section{Total Mass Balance for 2010}

Terminus positions were traced off 2009 and 2010 orthorectified air photos, and area change due to calving losses was estimated. The region of calving losses was gridded on a $350 \mathrm{~m}$ grid, and each cell was scaled by the ice thickness in that area as determined using a continuity-based ice thickness algorithm (for example, O'Neel and others, 2005). Incorporating the measured geometry changes of $-1.5 \times 10^{9} \mathrm{~m}^{3}$ from calving losses adjusts the total mass loss to $-3.55 \times 10^{9} \mathrm{~m}^{3}$ w.e., which still neglects mass change due to flow and thinning over the existing glacier area. The most recent published value for calving losses flux is $7.3 \times 10^{9} \mathrm{~m}^{3}$ w.e. for 2000 (O'Neel and others, 2005). Considering the 2000 calving flux as representative of present fluxes, and noting the minimal glacier area change for 2000 (Krimmel, 2001), suggests a thinning flux of approximately $-6 \times 10^{9} \mathrm{~m}^{3}$ w.e., and a total mass loss for 2010 of approximately $-9.5 \times 10^{9} \mathrm{~m}^{3}$ w.e. These back-of-the-envelope calculations suggest that calving losses are 3 to 4 times greater than surface-forced losses, because modern calving fluxes are not available.

\section{Summary}

Two years of direct surface mass balance estimates are presented for Columbia Glacier, Alaska. Although interannual variability of the surface balance is large due to the highly variable nature of coastal Alaska's winter precipitation rates, the analysis demonstrates that a large fraction of the dramatic mass losses from Columbia Glacier (approximately $150 \mathrm{~km}^{3}$ ) since the onset of rapid retreat in the early 1980s is not a result of surface mass balance forcing. The analysis confirms the importance of dynamic instability during rapid retreat. To better understand the role of interannual variability, surface mass balance measurements continued during 2011, and an analysis of mass balance partitioning between surface and dynamic forcing is underway.

\section{Acknowledgments}

The work performed in this study was made possible by skilled piloting provided by Keith Essex, Andy Wallace, Marcus Roulet, and Mike Meekin. Field assistance from Louis Sass, Ethan Welty, Eric Nilan, Alice Bradley, and Tad Pfeffer made it possible to complete the work under intense time constraints. Rod March gave invaluable insight into the history of the survey control network at Columbia Glacier. Al Rasmussen and Chris Larsen provided reviews that greatly enhanced the quality of the manuscript. 


\section{References Cited}

Arendt, A., Echelmeyer, K., Harrison, W., Lingle, C., Zirnheld, S., Valentine, V., Ritchie, B., and Druckenmiller, M., 2006, Updated estimates of glacier volume changes in the western Chugach Mountains, Alaska, and a comparison of regional extrapolation methods: Journal of Geophysical Research, v. 111,12 p., doi:10.1029/2005JF000436, accessed December 28, 2011, at http://www.agu.org/pubs/ crossref/2006/2005JF000436.shtml.

Berthier, E., Schiefer, E., Clarke, G.K.C., Menounos, B., and Rémy, F., 2010, Contribution of Alaskan glaciers to sea-level rise derived from satellite imagery: Nature Geoscience, v. 3, p. 92-95.

Cogley, J.G., Hock, R., Rasmussen, L.A., Arendt, A.A., Bauder, A., Braithwaite, R.J., Jansson, P., Kaser, G., Möller, M., Nicholson, L., and Zemp, M., 2011, Glossary of glacier mass balance and related terms: Paris, International Association of Cryospheric Sciences, IHP-VII, Technical Documents in Hydrology, v. 86, 124 p.

Cuffey, K.M, and Paterson, W.S.B, 2010, The physics of glaciers: Academic Press, $704 \mathrm{p}$.

Krimmel, R.M., 2001, Photogrammetric data set, 1957-2000 and bathymetric measurements for Columbia Glacier, Alaska: U.S. Geological Survey Water-Resources Investigations Report 01-4089, 46 p.

Mayo, L.R., Trabant, D.C., March, R., and Haeberli, W., 1979, Columbia Glacier stake location, mass balance, glacier surface altitude, and ice radar data 1978 measurement year: U.S. Geological Survey Open File Report 79-1168, 72 p.

Meier, M.F., and Post, A., 1987, Fast tidewater glaciers: Journal of Geophysical Research, v. 92, no. B9, p. 9,051-9,058.

O’Neel, Shad, Pfeffer, W.T., Krimmel, Robert, and Meier, Mark, 2005, Evolving force balance at Columbia Glacier, Alaska, during its rapid retreat: Journal of Geophysical Research, v. 110, 18 p., doi:10.1029/2005JF000292, accessed December 28, 2011, at http://www.agu.org/pubs/ crossref/2005/2005JF000292.shtml.
O’Neel, Shad, Marshall, H.P., McNamara, D.E., and Pfeffer, W.T., 2007, Seismic detection and analysis of icequakes at Columbia Glacier, Alaska: Journal of Geophysical Research, v. 112, 14 p., doi:10.1029/2006JF000595, accessed December 28, 2011, at http://www.agu.org/pubs/ crossref/2007/2006JF000595.shtml.

Pfeffer, W.T., 2007, A simple mechanism for irreversible tidewater glacier retreat: Journal of Geophysical Research, v. 112, 12 p., doi:10.1029/2006JF000590, accessed December 28, 2011, at http://www.agu.org/pubs/ crossref/2007/2006JF000590.shtml.

Pfeffer, W.T., Harper, J.T., and O’Neel, Shad, 2008, Kinematic constraints on glacier and land ice contributions to 21st century sea level rise: Science, v. 321, p. 1,340-1,343.

Rasmussen, L.A., Conway, H., Krimmel, R.M., and Hock, R. 2011, Surface mass balance, thinning and iceberg production, Columbia Glacier, Alaska, 1948-2007: Journal of Glaciology, v. 57, no. 203, p. 431-440.

Thompson, G., and West, M.E., 2010, Real-time detection of earthquake swarms at Redoubt Volcano, 2009: Seismological Research Letters, v. 81, no. 3, p. 505-513, doi: 10.1785/gssrl.81.3.505.

Van den Broeke, M., Bamber, J., Ettema, J., Rignot, E., Schrama, E., van de Berg, W.J., van Meijgaard, E., Velicogna, I., and Wouters, B., 2009, Partitioning recent Greenland mass loss: Science, v. 326, no. 5,995, p. 984986, doi:10.1126/science.1178176.

Walter, Fabian, O'Neel, Shad, McNamara, Daniel, Pfeffer, W.T., Bassis, J.N., and Fricker, H.A., 2010, Iceberg calving during transition from grounded to floating ice-Columbia Glacier, Alaska: Geophysical Research Letters., v. 37, 5 p., doi:10.1029/2010GL043201, accessed December 28, 2011, at http://www.agu.org/pubs/crossref/2010/2010GL043201. shtml. 
Publishing support provided by the U.S. Geological Survey

Publishing Network, Tacoma Publishing Service Center

For more information concerning the research in this report, contact the

Director, Alaska Science Center

U.S. Geological Survey

4210 University Drive

Anchorage, Alaska 99508

http://alaska.usgs.gov 
